\section{A buyers' market}

Walter Gratzer

Communicating Science to the Public. Edited by David Evered and Maeve O'Connor. Wiley: 1987. Pp.214. £28.95, \$49.95.

THERE was once an entrancing headline in a British newspaper, which ran: Incest more common than thought in United States. Well, the news is that it may be true. At least on the evidence deployed by Alan J. Friedman, who brings these symposium proceedings to their sombre close, unreason reigns, and education, by inexorable inference, has been a failure. Fiftyfive per cent of American teenagers believe for instance that astrology works. As for the British, seventy-five per cent are persuaded that it is a scientific discipline. This, it appears, is often held to follow (well, who can doubt it?) from the well-known circumstance that astrologers use computers. Nor is it only the common multitude that holds such convictions, for President Reagan owns to being guided by his horoscope. "I believe you'll find", he says, "that $80 \%$ of the people in New York's Hall of Fame are Aquarians". Friedman has even discovered a member of the Faculty of Columbia University (admittedly a psychiatrist) with closely similar opinions.

Ours is an age that will chiefly be remembered by history for its scientific and technological achievements. Why then should it matter if a large proportion of our populace believes that oysters engender lust and that the Milky Way is God's daisy chain? The learned group of experts, who were brought to the Ciba Foundation to consider this and similar questions, return no very clear answer. Dr Miller from the Public Opinion Laboratory of Northern Illinois University quotes one I.C. Davis, writing 50 years ago, that he who has acquired the scientific attitude will:

(1) show a willingness to change his opinion on the basis of new evidence [though this was C.M. Bowra's reason for regarding scientists as unpredictable and therefore dangerous on academic committees]; (2) will search for the whole truth without prejudice; (3) will have a concept of cause and effect relationships; (4) will make a habit of basing judgement on fact; and (5) [most stirring of all] will have the ability to distinguish between fact and theory.

W.M. Laetsch, from Berkeley, in a magisterial opening chapter, makes short work of such pompous bunkum, which still often emanates from committees of scientists. One of my own favourite examples comes from Karl Pearson, the geneticist (a calling that seems to predispose to fatuous utterances on social issues): "Modern science, as training the mind to an exact and impartial analysis of facts, is an education specially fitted to promote citizenship". Not so very long ago it was regarded as self-evident, at least in Britain, that this was uniquely the attribute of a classical education. (And in the United States the introduction of the BSc

"It is in reality a matter of observation that scientists given to public vociferation on subjects not their own will too often cast off the constraints of caution and intellectual honesty that vex them in the laboratory. We all know that no proposition is so foolish or meretricious that at least two Nobel laureates cannot be found to endorse it."

degree drew the following comment from a Dean of Harvard: "It does not guarantee that the holder knows any science, but it does guarantee that he does not know any Latin".) It is in reality a matter of observation that scientists given to public vociferation on subjects not their own will too often cast off the constraints of caution and intellectual honesty that vex them in the laboratory. We all know that no proposition is so foolish or meretricious that at least two Nobel laureates cannot be found to endorse it.

Laetsch's conclusion, which is both wholesome and refreshing, is that ultimately the teaching of science must be defended, like all other forms of education, on the grounds that it is able to give pleasure and enrich life. Now it would, I think, be paltering with the truth to pretend that our activities do as much in the cultural line for the public at large (especially at the price) as say the London Philharmonic playing in the Festival Hall. The standards for a start are lower; most science is too narrow or trivial to give pleasure even to other scientists. It was not always so: in Victorian times scientific discoveries formed the substance of improving after-dinner entertainments for the family; collections of microscope slides and The Origin of Species probably reposed on the shelf in most homes with any pretension to culture. More recently, the three-volume popular treatise on biology, by H.G. and G.P. Wells and Julian Huxley, enjoyed enormous success. H.G. took the enterprise very seriously. "The job", he wrote to Julian Huxley, "is an important job; your own researches and your professional career are less important".

What then has gone wrong? Geoff Deehan of the BBC writes entertainingly of the broken-backed and half-hearted attempts by scientists (especially the British) to explain their work to the public. Rutherford said that no theory was to be taken seriously that could not be explained to a barmaid, and this is surely an enduring truth. A recurring theme of the book is that scientists have little interest in repaying society in the same coin. According to Dorothy Nelkin, they see the mass media only as engines of political persuasion, especially when times are hard. Here is a newspaper editor, quoted in her discourse on science and the media:

When NSF money was available easily, you couldn't get a story out of a molecular biologist. Today I get copies of grant applications in the mail with this thing, 'single cure for blank or whatever it might be', circled in red, saying 'we need all the help we can get, fellers'.

Nelkin has another good illustration: a New York Times science writer surveyed, evidently with circumspection and objectivity, the state of progress on interferons, and cautioned his readers not to expect miracles. This drew a complaint to the editor from a group of scientists that such a cool evaluation could jeopardize their funding.

The generally unflattering picture of scientists that emerges from these pages is compounded in Alan Friedman's contribution by our image in fact and fiction. Here is a students' eye view:

He neglects his family - pays no attention to his wife, never plays with his children - He has no social life, no other intellectual interests... $\mathrm{He}$ bores his wife, his children and their friends... . He is always running off to his laboratory. He may force his children to become scientists also.

Oh, well - better perhaps than W.H. Auden:

To the man in the street, who I'm sorry to say Is a keen observer of life,

The word intellectual suggests straight away A man who's untrue to his wife.

It is curious perhaps to find a symposium on the communication of science that has no contributions from the great popular communicators, or indeed (except in the discussions) from any scientists. There are, at least to my untutored taste, too many of the kind of sociological effusions that flutter out of Departments of Education like bats out of a barn. But there are some excellent chapters, in between the longueurs. It is a worthwhile enterprise and merits a $\beta(+$ ?) for earnest good intentions.

Walter Gratzer is in the Medical Research Council Cell Biophysics Unit, King's College London (KQC), 26-29 Drury Lane, London $W C 2 B 5 R L, U K$ 